Semina $\square \quad \mathrm{Nr} 13$

Scientiarum 2014

s. $79-103$

DOI: http://dx.doi.org/10.15633/ss.686

Michał Nakoneczny

\title{
Jerrolda Levinsona ontologia dzieł muzycznych a zagadnienie indywidualnej esencji dzieła muzycznego
}

W niniejszej pracy analizuję rodzaj esencjalizmu metafizycznego, jaki wynika ze strukturalistycznej teorii dzieł muzycznych Jerrolda Levinsona. W pierwszym kroku zarysowuję najważniejsze elementy propozycji Levinsona, szczególnie wiernie oddając i analizując przesłanki, na których się wspiera oraz linię argumentów, które formułuje.

W drugiej części pracy wprowadzam argument za koniecznościa indywidualnych esencji Mackie ${ }^{1}$ i Forbesa ${ }^{2}$. Przenoszę ich przykłady na grunt filozofii muzyki, aby pokazać, że problem ten dotyczy również dzieła muzycznego.

W części trzeciej, ostatniej, pokazuję, że z przedstawionej w pierwszej części linii argumentacji Levinsona wyłania się obraz ontologii muzyki spójny z postulatem indywidualnych esencji Mackie i Forbesa. Twierdzę jednak, że pomimo iż Levinson słusznie postuluje, że dzieło muzyczne posiada cechy istotnościowe, to jednak jego wybór tych cech prowadzi do kontrintuicyjnych wniosków. Pracę kończę autorskim argumentem za zachowaniem postulatu esencjonalności niektórych cech dzieła muzycznego, ale sugeruję, że powinny to być cechy inne od tych, które wskazuje Levinson.

Zob. P. Mackie, How Things Might Have Been, Oxford 2009.

2 Zob. G. Forbes, The Metaphysics of Modality, Oxford 1985. 
Praca ta ma dwa cele. Po pierwsze, proponuję w niej dodatkowe uzasadnienie dla tezy Levinsona o konieczności niektórych cech dzieł muzycznych: rozpoczynam od uzasadnienia intuicji modalnych przez uzus językowy oraz adaptuję argument Forbesa za koniecznością postulowania indywidualnych esencji na grunt filozofii muzyki. Po drugie, formułuję własny argument przeciwko esencjalizmowi Levinsona: w części czwartej udowadniam, że Levinson w nieuprawniony sposób próbuje ugruntować tożsamość dzieł w części na własnościach relacyjnych, z czego (w równie nieuprawniony sposób) wyciaga wnioski odnośnie do status modalnego tych cech. W tej pracy formułuję kontrargument do tego skrajnego stanowiska Levinsona.

Odnajduję wartość w dyskusji na temat statusu modalnego cech dzieł muzycznych ze względu na niewielką objętość literatury, która podejmuje to zagadnienie. W przeciwieństwie do dyskusji na temat istotnościowych cech wykonań dzieł muzycznych zagadnienie istotnościowych cech samych dzieł muzycznych pozostaje niezbadane.

\section{Definicje}

Za Mackie przyjmuję następujące definicje:

Esencjalizm: pogląd filozoficzny, zgodnie z którym przedmioty partykularne posiadaja niektóre ze swoich cech z konieczności;

cecha konieczna: cecha, bez której przedmiot nie mógłby istnieć; cecha przygodna: cecha, którą przedmiot posiada, ale bez której mógłby istnieć;

indywidualna esencja: cecha lub zbiór cech przedmiotu $A$, które z konieczności są zarówno konieczne, jak i wystarczające do bycia $A$.

$\mathrm{Z}$ tezy esencjalistycznej wyłania się obraz przedmiotów, zgodnie z którym nie mogłyby one istnieć bez swoich koniecznych cech. Twierdzenie, że nie wszystkie cechy są konieczne, jest równoznaczne intuicji, że rzeczy mogłyby się mieć inaczej, niż mają się w rzeczywistości; natomiast twierdzenie, że niektóre cechy sa konieczne równa się twierdzeniu, że istnieje pewna granica co do tego, jak różnie i inaczej te rzeczy mogłyby się mieć. Cechy konieczne będę również wymiennie nazywał - za bogatą polską literatura przed- 
miotu - cechami istotnościowymi. Wybrane cechy drugiego rzę$\mathrm{du}$ - cechę bycia cechą konieczną (in. istotnościowa) i cechę bycia cechą przygodną będę dla prostoty nazywał statusem modalnym.

$\mathrm{Z}$ definicji indywidualnej esencji wynika, że jeśli cecha (albo zbiór cech) $\varphi$ jest indywidualna esencją $A$, to $A$ ma $\varphi$ z konieczności ( $\varphi$ jest cechą konieczna $A$ lub zbiorem koniecznych cech $A$ ) i żaden inny przedmiot nie posiada (faktycznie lub tylko możliwie) $\varphi$.

Wielokrotnie już użyte wyrażenia 'mógłby', 'mogłaby', np. w twierdzeniu, że „przedmioty nie mogłyby istnieć bez swoich koniecznych cech”, albo że „rzeczy mogłyby się mieć inaczej, niż mają się w rzeczywistości” należy rozumieć jako możliwość metafizyczna, którą będę dla prostoty eksplikował, używając teorii światów możliwych. Istnieją inne możliwe drogi redukcji twierdzeń modalnych, ale te teorie nie będą przedmiotem owej pracy, tak samo, jak nie zajmuję się tutaj obroną teorii światów możliwych. W języku teorii światów możliwych łatwo wyjaśnić, że jeśli $\varphi$ jest indywidualną esencja, to za pomoca $\varphi$ można wyróżnić i odnaleźć $A$ we wszystkich światach możliwych, w których $A$ istnieje.

$\mathrm{W}$ pracy tej podejmuję się zadania nakreślenia teoretycznych granic pomiędzy koniecznymi i przygodnymi cechami dzieła muzycznego oraz poszukiwania cech, które można uznać za indywidualne esencje dzieł muzycznych. Aby wykonać to zadanie, wychodzę od argumentu Mackie za indywidualnymi esencjami, a przeciw nagim tożsamościom.

\section{Teoria strukturalistyczna Jerrolda Levinsona}

Levinson ${ }^{3}$ rozpoczyna konstruowanie swojej teorii od zaakceptowania intuicji strukturalistycznych Stevensona ${ }^{4}$, Margolisa ${ }^{5}$ i Wol-

3 J. Levinson, What a Musical Work Is, „Journal of Philosophy” 1980, t. 77, nr 1, s. 5-28; oraz J. Levinson, Music, Art, and Metaphysics: Essays in Philosophical Aesthetics, Ithaca 1990.

4 C. L. Stevenson, On „What is a Poem?”, „Philosophical Review” 1957, t. 66, nr 3, s. 329-362.

5 J. Margolis, The Language of Art \& Art Criticism, Wayne 1965. 
lheima ${ }^{6}$, przyjmując za punkt rozpoczęcia głębszych dociekań fakt, że dzieło muzyczne jest jakiegoś rodzaju przedmiotem abstrakcyjnym oraz że jest jakiegoś rodzaju strukturą. Ponieważ Levinsona głos w tej dyskusji wpisuje się w nurt krytyki naiwnego strukturalizmu, nie odnajdujemy w jego teorii argumentu explicite broniącego tak poczynionego szerokiego założenia strukturalistycznego. Zdaje się on być tak nieorozerwalnie z nurtem strukturalistycznym związany, że milcząco tę tezę zakłada.

Levinsona uzasadnienie tezy o abstrakcyjności dzieł muzycznych, w przeciwieństwie do uzasadnienia tezy strukturalistycznej, jest jasno wyłożone. Jego argument sprowadza się do wyliczenia kandydatów na nieabstrakcyjne przedmioty tożsame z dziełem muzycznym, a nieodpowiedniość tych utożsamień stanowi uzasadnienie skupienia dalszych dociekań jedynie na przedmiotach abstrakcyjnych. Rozpoczyna on od obserwacji, że dzieło muzyczne nie może być tożsame z samymi dźwiękami, z partytura, ani z doświadczeniem ${ }^{7}$. Powtarzanie tych przykładów jest $\mathrm{w}$ tym miejscu nieinteresujące.

Levinsona argument za strukturalizmem złożonym, lub - jak będę go nazywał - strukturalizmem inicjowanym, i jednocześnie argument przeciwko naiwnemu strukturalizmowi Stevensona i Wolheima, jest nowatorski. Odnosząc się do teorii Stevensona i Wolheima, Levinson formułuje cztery argumenty przeciwko dziełom muzycznym jako strukturom dźwięków simpliciter.

W następnych akapitach analizuję krytyczne argumenty Levinsona, pokazuję, w jaki sposób wyłania on z nich kryteria dla udoskonalonej ontologii dzieł muzycznych, i wybieram elementy, z których w następnym kroku formułuję niepożądane konsekwencje jego teorii. W szczególności analizuję zaangażowanie Levinsona w silny esencjalizm i niespójność pomiędzy osadzeniem jego teorii w teorii typów i egzemplarzy a kryterium komponowalności.

6 R. Wollheim, Art and its Objects, Cambridge 1968.

7 J. Levinson, What a Musical Work Is, dz. cyt., s. 5. 
Levinson rozpoczyna formułowanie swojego stanowiska od zauważenia, że w żadnej teorii utożsamiającej dzieła muzyczne z prostymi strukturami dźwięków kompozytor nie tworzy swoich utworów. Argument, który tego dowodzi, jest następujący: proste struktury dźwięków (a są one według Levinsona zbudowane nie tylko z następujacych po sobie częstotliwości w określonym rytmie, ale należą do nich wszystkie te cechy, które nazywamy czysto słyszalnymi, a więc również barwy dźwięku, ich dynamika i akcentowanie) to nic innego jak proste, ponadczasowe typy.

Argument 2.1. Ponadczasowe istnienie prostych typów wynika stąd, że typ istnieje zawsze tam, gdzie może mieć wystapienia, innymi słowy - ustanowienie możliwości wystapienia egzemplarzy jest wystarczająca przesłanką do stwierdzenia istnienia typu.

Wynika z tego zatem, że proste struktury (tu: dźwięków) (oraz proste typy dźwiękowe, z których się składaja, np. triada molowa f, albo środkowe C na klarnecie), które zawsze mogły mieć swoje egzemplarze, istnieja ponadczasowo. To logicznie możliwe, że struktura dźwiękowa zgodna z dźwiękami, z których składa się kwintet Beethovena opus 16, zaistniała w erze paleozoicznej, a już na pewno taka struktura mogła zaistnieć w 1760 roku, tj. na 10 lat przed narodzinami Beethovena. A skoro struktura mogła mieć wystapienia - konkluduje Levinson - to z pewnościa mogła istnieć.

Z twierdzenia, że ustanowienie możliwości wystapienia egzemplarzy jest wystarczająca przesłanką do stwierdzenia istnienia typu odczytuję, że Levinson odżegnuje się od konkurencyjnego poglądu, zgodnie z którym powiedzenie, że pewna struktura może mieć wystapienia $\mathrm{w}$ czasie $t$ nie zobowiąuje do uznania istnienia tej struktury w czasie $t$, a jedynie powiedzenia, że gdyby miała wystapienia, to by istniała. Innymi słowy - do powiedzenia, że struktura powstaje razem ze swoim pierwszym wystapieniem i nie wcześniej od niego. Powodem, dla którego Levinson nie obiera tej drugiej, prostszej drogi i zarazem drugim argumentem przeciwko dziełom muzycznym jako prostym strukturom dźwięków, jest argument $\mathrm{z}$ aksjomatu ekstensjonalności: 
Argument 2.2. Jeśli uznać, że proste dźwięki, z których składaja się proste struktury dźwiękowe istnieją wiecznie [z A.2.1.] i jeśli bronić poglądu, że struktury dźwiękowe są zbiorami, albo innymi teoriomnogościowymi obiektami, których jedynymi konstytuentami sa ich elementy, to jasne się staje, że struktury dźwięków istnieją gdy tylko istnieją dźwięki, z których się składaja.

Wobec dwu powyższych argumentów, utożsamienie dzieł muzycznych z prostymi strukturami dźwiękowymi jest równoznaczne z bronieniem poglądu, że dzieła muzyczne są obiektami ponadczasowymi, a w szczególności, że nie są komponowalne. Obawa przed takimi konsekwencjami skłania Levinsona do sformułowania pierwszego kryterium pożądanej teorii, kryterium komponowalności:

Dzieła muzyczne nie istnieja przed działalnościa kompozytora - komponowaniem. Dzieła muzyczne sa tworzone przez tę aktywność 8 .

Levinson szuka uzasadnienia dla takiej zasady, a nie przyjmuje jej jako prymitywnej intuicji. Pierwsze, najsłabsze uzasadnienie płynie z codziennej praktyki: z faktu, że oceniamy dzieła muzyczne i podziwiamy tych kompozytorów, których dzieła uznajemy za wybitne. Status, który przypisujemy kompozycjom, zależy od dzieł komponowanych przez ich kompozytorów: jeślibyśmy twierdzili, że Piata symfonia Beethovena istniała przez Beethovenem, to - twierdzi Levinson - jakaś mała część chwały otaczająca Beethovena by znikła 9 .

Po wtóre, można za tezą komponowalności wytaczać argument etyczny lub prawny: Levinson twierdzi, że istnieje relacja „Ja-Ty” pomiędzy artystą i jego dziełem: relacja wyłącznego posiadania, zgodnie z która dzieło należy do autora w najprostszym tego słowa znaczeniu. Taka intuicja posiadania dzieła może zostać uchwy-

8 Tamże, s. 9 (tłum. własne).

9 J. Levinson, Music, Art..., dz. cyt., s. 67. 
cona tylko wtedy, gdy artysta dosłownie posiada swoje dzieło, tzn. jest jego twórca ${ }^{10}$.

Ostateczne i najsilniejsze uzasadnienie płynie zaś z języka. Sposób, w jaki mówimy o kompozytorach i ich pracy, zawiera już w sobie tezę, że dzieła są tworzone, a nie odkrywane:

Nie istnieje myśl bliższa centrum myślenia o sztuce, niźli to, że sztuka to czynność, w której artyści tworzą nowe rzeczy - dzieła sztuki. Cała tradycja sztuki zakłada kreatywność w najściślejszym sensie, to jest kreatywność niczym boską kreację, w której artyści przynoszą na świat to, co nie istniało, niczym demiurg kształtujacy świat $\mathrm{z}$ bezkształtnej materii. Myśl, że artyści sprawiaja, że coś nowego zaczyna istnieć, razem z piekarzami, murarzami, prawnikami i teoretykami, jest bez wątpienia bardzo głęboko zakorzeniona i domaga się uchowania, jeśli to tylko możliwe ${ }^{11}$.

Pozwalam sobie nie czynić w tym miejscu dygresji na potrzeby oceny tych uzasadnień, aby nie przerywać wywodu teorii Levinsona. Do krytycznej oceny wszystkich kroków w argumentach Levinsona powracam na końcu tej części pracy.

Powracając do obiekcji przeciwko prostemu strukturalizmowi, Levinson zauważa, że gdyby dzieła muzyczne nie były niczym innym niż prostymi strukturami dźwiękowymi, to dwu kompozytorów opisujących tę samą strukturę skomponowałoby z konieczności (z aksjomatu ekstensjonalności) to samo dzieło. Jeśli natomiast zgodzimy się z tym, że komponowanie jest tworzeniem, to, naturalnie, nie da się skomponować tego samego dzieła w różnych chwilach.

Kompozytorzy, którzy zapisują taką samą partyturę, w tym samym systemie notacji, z tymi samymi konwencjami co do interpretacji, opisują tę samą strukturę dźwiękowa. Ale - twierdzi Levinson - dzieła muzyczne, które w ten sposób skomponuja, nie sa identyczne. Dzieje się tak dlatego, że pewne cechy dzieła muzycznego zależą od czynników innych niż tylko kolejno użyte dźwięki.

10 Tamże, s. 218.

11 J. Levinson, What a Musical Work Is, dz. cyt., s. 8. 
Argument 2.3. (1) Estetyczne i artystyczne cechy dzieła muzycznego są w części funkcją i muszą być ocenianie nierozłącznie z muzyczno -historycznym kontekstem, w którym znajdował się kompozytor w czasie kompozycji [milczące założenie kontekstualizmu]. (2) Dwu kompozytorów nie może w całości znaleźć się w tym samym kontekście muzyczno -historycznym [z zarysu definicji kontekstu muzyczno-historycznego poniżej]. (3) Dzieła dwu kompozytorów osadzone na tej samej strukturze dźwiękowej, przejawiaja inne cechy estetyczne i artystyczne [z 1 i 2$]$. Ergo, dzieła dwu kompozytorów, choćby osadzone na tej samej strukturze dźwięków, są numerycznie nietożsame [z 3 i prawa Leibniza].

Nazwijmy ten argument, na potrzeby przyszłej krytycznej analizy, argumentem z kontekstualizmu.

Nie dając pełnej definicji, Levinson zauważa tylko, że muzyczno-historyczny kontekst kompozytora $P$ w czasie $\mathrm{w} t$ składa się przynajmniej z:

1. całości historii kulturowej, społecznej i politycznej do $t$;

2. rozwoju muzyki do $t$;

3. stylów muzycznych dominujacych w czasie $t$;

4. działalności kompozytorów współczesnych $P \mathrm{w}$ czasie $t$;

5. $\quad$ stylu $P$ w czasie $t$;

6. repertuaru $P$ w czasie $t$;

7. wszystkich zebranych dzieł $P$ do $t$;

8. muzycznych wpływów działających na $P$ w czasie $t$.

A zatem, w pożądanej teorii, kompozytorzy tworzący w różnych kontekstach muzyczno-historycznych, nawet jeśli opiszą tę samą strukturę, skomponują różne dzieła muzyczne.

Trzecia obiekcja Levinsona mówi, że gdyby dzieła muzyki były tylko strukturami dźwiękowymi, to środki wykonania - instrumentarium - byłyby jedynie przygodne dla dzieła, podczas gdy Levinson uważa je - przynajmniej w rozważanych, paradygmatycznych przypadkach - za konieczne. Argument za tym, że instrumentarium jest konieczne, jest taki, że kompozytorzy wskazują instrumentarium podczas komponowania oraz taki, że wspomniane wcześniej cechy estetyczne i artystyczne znowu są w części funkcją wybranego instrumentarium. 
Argument 2.4. Jeśli sonata Hammerklavier Beethovena byłaby napisana na coś innego, to nie byłaby już tak wyniosła, porywista i wzbudzająca trwogę. Estetyczne atrybuty sonaty Hammerklavier wynikają po części z wysiłku, jaki nakłada na pianino ${ }^{12}$. A zatem, zmiana instrumentarium spowodowałaby zmianę tożsamości dzieła. Ergo, instrumentarium wykonania jest esencjalne dla samego dzieła.

Argument 2.5. W barokowych koncertach na dwoje skrzypiec, takich jak Bacha koncert d-moll, BWV1043, często odnajdujemy frazę (A) jednych skrzypiec, po której od razu następuje ta sama fraza (B) drugich skrzypiec. Gdy słyszymy te dwie frazy wykonane przez dwoje skrzypiec (nawet jeśli w konkretnym wykonaniu różnice w barwie A i B sa nieodróżnialne), słyszymy rodzaj nieponaglanego, zrelaksowanego dialogu. Gdybyśmy skonstruowali takie frazy jako partyturę na jedne skrzypce, to te własności zostałyby zatracone. W ich miejsce, ten fragment stałby się bardziej emfatyczny, niepokojący i powtarzal$n y^{13}$. Ergo, instrumentarium wykonania jest esencjonalne dla samego dzieła.

Z powyższych obiekcji wynika, że dzieło muzyczne nie jest prostą strukturą dźwięków. Levinson postuluje, że jest ono przynajmniej dwiema strukturami - strukturą dźwięków i strukturą środków wykonania (implementacji instrumentarium). Od razu jednak widzimy, że struktura dźwięków i środków wykonania (sound and performance-means: S/PM), podobnie jak - co widzieliśmy w obiekcji pierwszej - struktura dźwięków i w ogóle każda inna struktura, której jedynymi egzemplarzami sa proste typy, jest nie mniej ponadczasowa i niekomponowalna co sama struktura dźwięków. Wobec tego Levinson proponuje przyjąć, że dzieło muzyczne to struktura dźwięków i środków wykonania (S/PM) wskazana przez kompozytora $X$ w czasie $t$.

W przeciwieństwie do typów prostych, typy wskazane przez $X \mathrm{w}$ czasie $t$ to typy zainicjowane - typy, które zaczynają istnieć

\footnotetext{
12 Tamże, s. 17-18.

13 Tamże, s. 18.
} 
dopiero wtedy, gdy zostaną wskazane w intencjonalnym akcie. Wskazanie, natomiast, odbywa się poprzez wyprodukowanie egzemplarza inicjowalnego typu lub przynajmniej prototypu takiego egzemplarza.

Dla zobrazowania swojej teorii inicjowalnych typów Levinson podaje trzy przykłady: Forda Thunderbirda, monety jednocentowej z wizerunkiem Abrahama Lincolna na awersie oraz jeża.

Argument 2.6. O modelu Thunderbird nie wystarczy powiedzieć, że jest prosta struktura metalu, szkła i plastiku. Ta abstrakcyjna stuktura, która jest ucieleśniona w modelu samochodu, mogła mieć swoje egzemplarze przynajmniej od wynalezienia plastiku w 1870 roku, a więc i odtąd istniała (zgodnie z poglądem z obiekcji pierwszej, powyżej), a już z pewnościa mogła mieć egzemplarze w 1900 roku, podczas gdy Thunderbird został stworzony dopiero w roku 1957, a więc wystapień Forda Thundebirda nie mogło być w roku $1900^{14}$. Ergo, Ford Thunderbird jest typem inicjowalnym - jest struktura metalu/szkła/plastiku wskazana przez firmę Forda w 1955 roku. Struktura ta zaczęła istnieć jako efekt ludzkiej pracy, a wystapienia Forda Thundebirda to coś więcej, niż wystapienia pewnej prostej plastikowo-szklano-metalowej struktury.

Argument 2.7. Podobnie jednocentówka nie jest prostą struktura, ale pewnym wzorem wskazanym przez rząd Stanów Zjednoczonych w 1909 r. Obiekty o takiej samej prostej strukturze, ale istniejące w roku $100 \mathrm{AD}$ w Cesarstwie Rzymskim nie byłyby egzemplarzami jednocentówki. Ergo, jednocentówka jest inicjowanym typem. Jeż to obrazowy przykład - pisze Levinson - gdyż nie powinniśmy uznawać jeży za prostą biologiczną strukturę, ale raczej za biologiczną strukturę zdeterminowana przez prawa ewolucji w pewnym momencie historii.

Argument 2.8. Stworzenia, które nazywamy, jeżami stoją w pewnych relacjach do innych stworzeń, które pojawiły się w innych momentach w czasie. Czysta, prosta, biologiczna struktura jeża mogłaby wy-

14 Tamże, s. 21-22. 
stapić w erze mezozoicznej albo na Uranie, ale nawet gdyby tak było, to nic z tych rzeczy nie mogłoby być jeżem. Ergo, jeż jest inicjowanym typem.

W przypadku muzyki wskazanie oznacza zapisanie partytury lub dowolne inne utrwalenie przepisu na wykonanie egzemplarza struktury, czyli wykonania utworu, który się komponuje.

Przenosząc powyższe obserwacje na zagadnienia autentyczności wykonania, Levinson twierdzi, że wykonanie nie tylko musi być całkowicie zgodne ze strukturą dźwięków i środków wykonania, ale również musi istnieć pewna intencjonalna relacja przyczynowo-skutkowa pomiędzy dziełem a wykonaniem, tak aby te egzemplarze struktury, które wykazują te same dźwięki przypadkowo i nieintencjonalnie (jak liście na wietrze), nie były wykonaniami. Wynika z tego zatem jasno, że nie wszystkie wykonania to instancje, ponieważ nie wszystkie wykonania są prawidłowe. Tylko prawidłowe wykonania dzieła sa instancjami tego dzieła.

Z przedstawionego powyżej wywodu wyłania się obraz dzieła muzycznego jako abstrakcyjnej i komponowalnej struktury dźwięków oraz wykonania zainicjowanych przez kompozytora w czasie kompozycji. Sformułowana teoria postuluje dzieła muzyczne jako abstrakcyjne w sensie nieczasoprzestrzennym, natomiast ich komponowalność zasadza się na relacji wskazania - choć dźwięki, a więc i struktury, których jedynymi elementami są dźwięki, to byty ponadczasowe, a więc niestwarzalne (niekomponowalne), to struktury dźwięków i środków wykonania wskazane przez kompozytora $X$ w czasie $t$ zaczynają istnieć dopiero w chwili wskazania, w chwili $t$. Struktura $S / P M-X$ - $t$ jest natomiast dziełem muzycznym wtedy i tylko wtedy, jeśli $X$ wskazał (tj. wypisał partyturę lub w inny sposób uporządkował dźwięki i nakreślił środki wykonania) strukturę $S / P M \mathrm{w}$ czasie $t$.

Najprościej i najbardziej obrazowo można opisać Levinsonowską koncepcję stwarzalności abstraktów następująco. Przed aktem kompozycji interesujący nas wycinek krajobrazu metafizycznego (interesujaccy, tj. muzyczny) zawiera tylko ponadczasowe i niestwarzalne dźwięki oraz ich wszelakie struktury, tak jak istnie- 
ją atomy i ich wszystkie możliwe zbiory. W chwili $t$, kompozytor $X$ wskazuje pewną strukturę, razem ze środkami wykonania, można rzec - wybiera pewną już istniejąca strukturę. Co bardzo ważne, ten wybór jest całkowicie kompatybilny z teoriami eternalistycznymi, w szczególności z platonizmem Petera Kivy'ego i Juliana Dodda. W momencie wskazania jednak, jeśli wierzyć Levinsonowi i na przekór Kivy'emu i Doddowi, krajobraz metafizyczny dramatycznie się zmienia i zostaje wzbogacony o obiekt, który jeszcze przed chwilą nie istniał. Powstaje nowy obiekt - struktura $S / P M$-wskazana-przez- $X$-w- $t$. Nie wystarczy powiedzieć, że $X$ wzbogacił już istniejąca $S / P M$ o kolejna relację, ponieważ oba obiekty po $t$ wykazują różne cechy: $S / P M$, jako czysta struktura dźwiękowa posiada tylko takie muzyczne cechy, jak bycie w tonacji molowej lub durowej, rozpoczynanie się od triady molowej f, albo środkowego $\mathrm{C}$ na klarnecie. $S / P M-X-t$ natomiast jest osadzona w muzyczno-historycznym kontekście kompozytora i przejawia wiele estetycznych i artystycznych cech, których prosta $S / P M$ nie posiada. Zatem, skoro mówimy o dwu jakościowo różnych obiektach, to nie może być mowy o ich ilościowej identyczności. W chwili kompozycji faktycznie powstaje nowy obiekt.

\section{Indywidualne esencje i nagie tożsamości}

Po powyższej analizie teorii dzieł muzycznych należy spróbować uogólnić obserwacje i spróbować odpowiedzieć na pytanie o to, które cechy dzieł muzycznych faktycznie sa cechami istotnościowymi, to jest odpowiedzieć na pytanie, jakie sa metafizyczne granice co do tego, jakie dzieła muzyczne mogtyby być.

Mackie słusznie zakłada, że przypisywanie przedmiotom jako koniecznych takich cech jak "bycie identycznym z samym sobą" albo „bycie symfonią albo nie-symfonią”, to jest takich, które charakteryzuja wszystkie przedmioty bez wyjątku prowadzi do wcale nieekscytującej i trywialnej wersji esencjalizmu metafizycznego. Winniśmy zatem zacząć od poglądu cokolwiek kontrowersyjnego, to jest od poglądu, że istnieją nie tylko cechy istotnościowe, ale że 
istnieją również indywidualne esencje - cechy esencjonalne, które sa właściwe tylko pojedynczym przedmiotom.

Wśród kandydatów na indywidualne esencje Mackie odnajduje nieekscytujące, trywialne przypadki: po pierwsze, jeśli założymy zasadę konieczności tożsamości Kripkego, to musimy zaakceptować, że jeśli przedmiot $A$ nie jest identyczny z $B$, to $A$ będzie posiadał pewną istotnościową cechę, której $B$ nie posiada - cechę „bycia identycznym z $A$ ” (jeśli nadto założymy, że ' $A$ ' jest sztywnym desygnatorem). Zatem, jeśli założymy zasadę konieczności tożsamości, to winniśmy założyć, że Księżycowy Pierrot Schönberga ma pewną istotnościową cechę, której nie ma nic innego - „bycie identycznym z Księżycowym Pierrotem”. Totė̇, jeśli „bycie identycznym z Księżycowym Pierrotem” i - generalizując - „bycie identycznym z $X$ ” jest konieczną cechą $X$-ów, to wynika z tego, że wszystkie $X$-y mają indywidualne esencje. Nie powinniśmy jednak - argumentuje Mackie - poprzestawać na takich trywialnych esencjach, ponieważ niepodobna wyciagnąć z nich interesujących wniosków o statusie modalnym cech, które nas interesuja. Powinniśmy raczej szukać takich cech, które sa nietrywialnie konieczne i wystarczające do bycia Księżycowym Pierrotem.

Po drugie, jak argumentował Alvin Plantinga ${ }^{15}$, jeśli wybierzemy cechę, która Księżycowy Pierrot ma jako jedyny (jak na przykład cecha bycia skomponowanym przez Schönberga w 1912 roku), to cecha ta, zrelatywizowana do świata (cecha „bycia skomponowanym przez Schönberga w 1912 roku w aktualnym świecie”) trywialnie spełni kryteria bycia indywidualną esencją Księżycowego Pierrota.

Po trzecie, niektórzy sugeruja, że Księżycowy Pierrot ma haecceitas: konieczną cechę „bycia Księżycowym Pierrotem”, która (w przeciwieństwie do cechy „bycia identycznym z Księżycowym Pierrotem") uważana jest za to, co sprawia, że jej posiadacz jest Księżycowym Pierrotem. Haecceitates pozostają jednak niewyjaśnione i nieanalizowalne.

15 A. Plantinga, The Nature of Necessity, Clarendon 1974, rozdz. 5, sek. 2. 
Interesujące będzie jedynie takie (kontrowersyjne) zagadnienie indywidualnych esencji, według którego na indywidualne esencje będą składać się cechy nietrywialne, niezrelatywizowane i niesprowadzalne do haecceitates.

Jednym z filozofów, którzy zdają się akceptować indywidualne esencje $\mathrm{w}$ powyższym sensie, jest Leibniz. Zgodnie z powszechna interpretacją twierdził on, że przedmioty posiadają każdą swoją cechę z konieczności, a zasada tożsamości nieodróżnialników gwarantowała nietrywialny sposób rozróżniania cech dwu dowolnych przedmiotów. Niepożądaną konsekwencją poglądu postulującego, że wszystkie cechy sa istotnościowe jest to, że przeczymy intuicji jakoby rzeczy mogły mieć się inaczej, niż zdarzyło się to w historii aktualnego świata. Zgodnie z neoleibnizjańską koncepcją Księżycowy Pierrot posiada nietrywialną indywidualną esencję, która składa się z jakiegoś podzbioru jego cech.

Jako odpowiedź na pytanie, które cechy partykularnych przedmiotów można wyróżnić jako ich esencje, Mackie przywołuje argument Forbesa. Forbes twierdził, że jeśli interpretujemy modalności de re za pomoca teorii światów możliwych i tożsamości w poprzek tych światów, to przyjmujemy zobowiązania ontologiczne, które moga być spełnione jedynie przez indywidualne esencje. Argument Forbesa mówi, że bez postulowania indywidualnych esencji nie możemy zagwarantować, że tożsamość obiektów w różnych światach możliwych będzie ugruntowana w innych cechach. Jego konkluzja brzmi: jeśli nie chcemy porzucić tożsamości przedmiotów w różnych światach możliwych (na przykład na rzecz teorii odpowiedników), musimy założyć, że istnieją indywidualne esencje.

Argument 3.1. [Argument $\mathrm{z}$ nieodróżnialności] ${ }^{16}$ Jeśli wszystkie obiekty maja indywidualne esencje, to nie może zajść numeryczna różnica pomiędzy indywiduami bez różnicy istotnościowej, tj. różnicy w ich istotnościowych cechach. Jeśli jednak nie wszystkie indywidua

16 Forbes i Mackie, rozważając również wersję esencjalizmu odnoszącego się do rodzajów naturalnych, formułują swoje argumenty na przykładzie ludzi. Ja przekładam ich argument na grunt filozofii dzieł muzycznych. 
mają indywidualne esencje, to nie ma powodu, dla którego nie mogłyby istnieć dwa obiekty, które mają te same cechy istotnościowe, a różnią się jedynie swoimi cechami przygodnymi.

Załóżmy na potrzeby argumentu, że dzieła muzyczne nie posiadają indywidualnych esencji. Nie ma zatem powodu, dla którego nie mogłyby istnieć dwa dzieła muzyczne, które miałyby takie same cechy istotnościowe, a różniłyby się jedynie cechami przygodnymi. Załóżmy, że Księżycowy Pierrot Schönberga i Symfonia nr 3 Espansiva Nielsena sa takimi dziełami.

Naturalnie, jest wiele cech, które Księżycowy Pierrot ma, a których brakuje Symfonii Nielsena, i na odwrót. Jednak, jeśli Księzycowy Pierrot i Symfonia maja te same cechy istotnościowe, to wszystkie faktyczne różnice pomiędzy nimi muszą zawierać się w ich cechach przygodnych. Jeśli Księżycowy Pierrot i Symfonia mają te same cechy istotnościowe, to wszystkie możliwości co do tego, jaki Księżycowy Pierrot mógł był być jest również możliwością co do tego, jaka Symfonia mogła była być, i na odwrót. A zatem, dowolna możliwa historia Księżycowego Pierrota jest możliwą historią Symfonii, tak długo jak ich szczegóły są sformułowane w sposób, z którego logicznie nie wynika, że dotyczą Księżycowego Pierrota. Nazwijmy takie sformułowania sformułowaniami historii „agnostycznymi co do właściciela”.

Rozważmy zatem możliwą historię Księżycowego Pierrota, która jest sformułowana (in. wyrażona) w sposób agnostyczny co do właściciela. Szczegóły takiej historii nie mają znaczenia, ale załóżmy, że jest to historia, w której Księżycowy Pierrot został skomponowany przez Mahlera, a nie Schönberga. Jeśli dowolna możliwa historia Księżycowego Pierrota jest możliwą historią Symfonii, to jeśli bycie skomponowanym przez Mahlera jest możliwą historią Księżycowego Pierrota, to musi również być możliwą historia Symfonii. Zdaje się zatem, że opisaliśmy dwa możliwe światy, $w_{1}$ i $w_{2}$, w każdym z których Mahler skomponował o jedną kompozycję więcej niż faktycznie, lecz w świecie $w_{1}$ jest to Księżycowy Pierrot, a w świecie $w_{2}$ jest to Symfonia. Ex hypothesi, Księzycowy Pierrot i Symfonia nie różnią się żadnymi cechami istotnościowymi, 
a zatem nie musi pomiędzy Księżycowym Pierrotem skomponowanym przez Mahlera w $w_{1}$, a Symfonią skomponowana przez Mahlera $\mathrm{w} w_{2}$ być żadnej różnicy. Jeśli założymy, że żadna różnica nie zachodzi, to światy $w_{1}$ i $w_{2}$ obrazują sytuację, która możemy nazwać „nagą różnica” tożsamości dodatkowej kompozycji Mahlera: to jest różnica, która nie zasadza się na różnicy w żadnych innych cechach tych światów.

Możemy pójść o krok dalej. Naszym początkowym założeniem było, że Księżycowy Pierrot i Symfonia nie różnią się swoimi cechami istotnościowymi; a zatem dowolna możliwa historia Księżycowego Pierrota jest możliwą historią Symfonii, i na odwrót. Jedna z takich historii mówiących, jaki Księżycowy Pierrot mógł był być, jest ta, która mówi, jaki faktycznie jest. A zatem musi ona stanowić możliwą historię Symfonii. Skonstruujmy zatem świat możliwy zawierający teoretyczne dzieło muzyczne - quasi-Księżycowego Pierrota - który jest nieodróżnialny od Księżycowego Pierrota, ale w istocie jest Symfonią Espensiva. W analogiczny sposób skonstruujmy świat quasi-Symfonii, która jest nieodróżnialna od Symfonii, ale jest tożsama z Księżycowym Pierrotem. Co więcej, nie ma powodu, dla którego nie mógłby to być jeden i ten sam świat możliwy.

W końcu, konkludujemy, istnieje taki świat możliwy, w którym zamieniliśmy tożsamość Księżycowego Pierrota z Symfonią Espansiva w sposób jakościowo nieodróżnialny, zakładając jedynie, że dzieła muzyczne nie maja indywidualnych esencji.

Ten „pomieszany” świat $w_{\mathrm{s}}$ obrazuje sytuację, którą możemy nazwać „nagimi tożsamościami”, ponieważ idea, że możemy koherentnie odróżnić $w_{1}$ od $w_{2}$ zdaje się być kontrintuicyjna. Jeszcze bardziej kontrintuicyjna zdaje się idea, że może istnieć świat $w_{\mathrm{s}}$, który jest nieodróżnialny od świata faktycznego, z tą tylko różnica, że tożsamość Księżycowego Pierrota i Symfonii są zamienione.

Jeśli dzieła muzyczne nie mają indywidualnych esencji, to moga istnieć pary dzieł muzycznych, które nie są odróżnialne przez swoje cechy konieczne. Zdaje się, że zagadnienie tożsamości, razem z pewnymi intuicyjnymi przekonaniami o modalnościach prowadzą do paradoksu nagich tożsamości, jeśli nie uznamy indywidualnych esencji. 


\section{Esencjalizm Levinsona}

W sekcji drugiej nakreśliłem, w jaki sposób indywidualne esencje dzieł muzycznych dają się wyprowadzić z kontekstualizmu muzyczno-historycznego Levinsona. Doprowadza nas to do konieczności analizy, które cechy dzieł muzycznych sa, wedle tej teorii, esencjalne.

Jak już zostało powiedziane w A.2.3, pewne artystyczne i estetyczne cechy dzieła muzycznego sa w części funkcją i muszą być ocenianie nierozłącznie $\mathrm{z}$ muzyczno-historycznym kontekstem, w którym znajdował się kompozytor w czasie kompozycji. Na ów kontekst składa się natomiast przynajmniej całość historii kulturowej, społecznej i politycznej do $t$; rozwój muzyki do $t$; style muzyczne dominujące w czasie $t$; działalność kompozytorów współczesnych $P$ w czasie $t$; styl $P$ w czasie $t$; repertuar $P$ w czasie $t$; wszystkie dzieła $P$ do $t$; i muzyczne wpływy działajace na $P$ w czasie $t$.

W pierwszej kolejności musimy zauważyć, że tak sformułowana teoria prowadzi do ekstremalnej wersji esencjalizmu muzycznego, zgodnie z którą wszystkie cechy zawarte w dziele muzycznym sa cechami koniecznymi - podobnie do filozofii Leibniza napomkniętej w części trzeciej tej pracy. Wśród takich cech Levinson wylicza częstotliwości kolejnych dźwięków, ich rytm, barwę, dynamikę i akcentowanie ${ }^{17}$; oraz instrumentarium ${ }^{18}$. Z definicji dzieła muzycznego zaś wynika dodatkowo, że zarówno osoba kompozytora, jak i czas kompozycji również są konieczne.

Zagadnienie esencjalizmu muzycznego w literaturze odnajdujemy głównie w odniesieniu do esencjalizmu wykonania, tj. podczas dyskusji o tym, jakich cech nie może zabraknąć wykonaniu, by było wykonaniem danego dzieła. Nie odnajdujemy natomiast dyskusji o esencjalizmie dzieł, tj. dyskusji o tym, które cechy dzieła muzycznego należą do niego z konieczności, a które z przypadku - których mogłoby mu zabraknać, a bez których nie mógłby istnieć. Jednak nawet bez odniesienia do innych stanowisk, stanowisko Levinso-

17 J. Levinson, What a Musical Work Is, dz. cyt., s. 6, przyp. 3.

18 Tenże, Music, Art..., dz. cyt., s. 14. 
na jest bezsprzecznie ekstremalne. Zgodnie z jego propozycją dowolny utwór nie mógłby zostać skomponowany z dowolnym innym dźwiękiem, rytmem, dynamika, akcentowaniem, na inny instrument, przez innego kompozytora, czy nawet w innej chwili, niż został faktycznie skomponowany.

Należy odpowiednio natężyć uwagę, aby zrozumieć siłę tego stwierdzenia. Nie mówimy tutaj o wykonaniach i o tym, których nut mogłoby zabraknać podczas koncertu. Nie mówimy o tym, że wykonanie Allegro maestoso Sinfonietty Janáčka bez fanfar byłoby wykonaniem wybrakowanym, jeśli w ogóle nadal wykonaniem Sinfonietty. Mówimy o tym, że ta Sinfonietta z konieczności rozpoczyna się od fanfar, z konieczności pierwsza część jest w Allegro, nie mogła być napisana na nic innego niż orkiestrę z rozbudowaną sekcją dętą i nie mogła zostać napisana przez nikogo innego niż Janáček. Innymi słowy, w każdym możliwym świecie utwory muzyczne (lub ich odpowiedniki, jeśli zaakceptować teorię Lewisa) składają się z dokładnie tych samych nut, w tym samym tempie i z identyczną artykulacją i dynamika, sa napisane przez tych samych kompozytorów i w dokładnie tym samym czasie. To zaiste przedziwny krajobraz metafizyczny, w którym utwory muzyczne sa jakościowo identyczne we wszystkich możliwych światach. Teoria ta stoi w jasnej sprzeczności z intuicjami mówiącymi, że np. „Beethoven mógł skomponować swój opus 16 rok wcześniej”, albo „Sinfonietta Janáčka mogła zostać napisana na dwa flety i jeden obój, zamiast trzech fletów i dwu obojów".

Jedynym autorem, który zdaje się podzielać moje intuicje, jest Carrier $^{19}$, który pisze:

Z pewnością niektóre własności dzieła sztuki [sonaty Beethovena] są przygodne. Sonata, którą Beethoven napisał czarnym atramentem w Wiedniu w marcu, mogła była być skomponowana w Salzburgu, w kwietniu. Beethoven mógł był użyć czerwonego tuszu do ostatnich nut. Deskrypcje „napisana w Wiedniu”, „napisana w marcu”, „zapisa-

19 D. Carrier, Art without Its Artists, „British Journal of Aesthetics” 1982, nr 22 , s. 233. 
na czarnym atramentem" nie odnosiłyby się wtedy do niej, ale przecież taka możliwa sonata nie jest innym dziełem sztuki.

Załóżmy, że podczas komponowania Beethoven kichnał 866 razy, a najwyższy człowiek w Pekinie zjadł 69 pierożków. Gdyby Beethoven kichną 867 razy albo ten najwyższy mężczyzna zjadł 70 pierożków, to deskrypcje „skomponowana podczas gdy Beethoven...” albo „skomponowana podczas gdy najwyższy...” nie odnosiłyby się do tej sonaty. To niepokojące. Ilość kichnięć Beethovena i ilość pierożków pożartych przez Chińczyków powinny być irrelewantne dla tożsamości sonaty ${ }^{20}$.

Nie odnajduję w What a Musical Work Is zobowiązania do twierdzenia, że wszystkie zdania dookreślające okoliczności kompozycji danego dzieła są konieczne. Wobec tego nie odnajduję poparcia dla tezy Carriera, że wyrażenia „skomponowana podczas gdy Beethoven kichnął 866 razy” albo „skomponowana podczas gdy najwyższy mężczyzna w Pekinie zjadł 70 pierożków” rzeczywiście stanowiąintuicyjny kontrprzykład do skrajnego esencjalizmu Levinsona. Później, w Music, Art, and Metaphysics sam Levinson odrzuca taka interpretację, pisząc „zgadzam się z nieistotnością kichnięć, pierożków, kolorów tuszu i umiejscowienia biurek, o których pisze Carrier”, ale jednocześnie jasno broniąc konieczności czasu kompozycji: „pozostawiam na boku kwestię komponowania w marcu albo kwietniu, gdyż to skrajny przypadek tego, co jednak uważam za wysoce istotne, to jest czasu zrelatywizowanego do innych kompozytorów i innych tradycji”'21.

Niewątpliwie zatem, jak napisałem powyżej, czas kompozycji jest istotnościowa cechą dzieła muzycznego zgodnie z definicją Levinsona, zatem w pierwszej części argumentu Carriera odnajduję poparcie dla mojej intuicji, że mamy dobre powody, aby sądzić, że część cech dzieł muzycznych, które Levinsona uważa za konieczne, jest w istocie jedynie przygodna.

Levinson formułuje 5 przykładów za takim rozumieniem tożsamości dzieła, mających przekonać czytelnika, że nawet struktural-

20 Tamże.

21 J. Levinson, Music, Art..., dz. cyt., s. 224. 
nie jakościowo nieodróżnialne dzieła moga przejawiać różne cechy estetyczne i artystyczne z powodu pochodzenia z różnego kontekstu muzyczno-historycznego:

Argument 4.1. (1) Dzieło identyczne w swojej strukturze z Księżycowym Pierrotem Schönberga z 1912 roku, ale skomponowane przez Richarda Straussa w 1897 byłoby estetycznie różne od dzieła Schönberga. Nazwijmy je Księżycowym Pierrotem*. Jako dzieło Straussa Księżycowy Pierrot* czerpałby z Requiem Brahmsa i byłby współczesny nokturnom Debussy'ego, a także byłby następny krokiem rozwoju Straussa po Tako rzecze Zaratustra. Jako taki byłby bardziej dziwaczny, niepokojący, bardziej udręczony i upiorny od dzieła Schönberga, ponieważ byłby postrzegany poprzez tradycję muzyczna, ówczesne style i ogół dzieł, w porównaniu do których charakterystyka struktury dźwiękowej Księżycowego Pierrota zdawałaby się skrajna.

Argument 4.2. (2) Mendelssohna uwertura do Snu nocy letniej (1826) jest powszechnie uważana za wysoce oryginalną kompozycję. Muzyka o tak kruchej delikatności i wyczuciu tonu nigdy wcześniej nie została napisana. Jednak partytura zapisana w 1900 roku opisująca tę samą strukturę, co ta odnaleziona u Mendelssohna, byłaby dziełem niezaskakująco nieoryginalnym.

Argument 4.3. (3) Brahmsa Sonata na pianino opus 2 (1852), jego wczesna praca, wykazuje silne wpływy Liszta, co słyszy każdy uważny słuchacz. Jednak dzieło o identycznej strukturze, ale napisane przez Beethovena, nie mogłoby być ukształtowane przez lisztowskie wpływy i miałoby pewną wizjonerską wartość, której dziełu Brahmsa brakuje.

Argument 4.4. (4) Symofnie Johanna Stamitza (1717-1757) sa uważane za nowatorski wkład w rozwój muzyki orkiestrowej. Używają wielu nowych dla swoich czasów, przyciagających uwagę środków, jeden z nich to „rakieta mannheimowska” - głośne pasaże unisono. Symfonia Stamitza zawierajaca rakiety mannheimowskie jest ekscytująca, ale utwór napisany dziś o strukturze identycznej z symfonia- 
mi Stamitza byłby nic tylko śmieszny. Symfonii Stamitza trzeba słuchać w kontekście wcześniejszych jego prac, stylu barokowego, działań młodego Mozarta i wojny napoleońskiej. Symfonie „współczesnego Stamitza” byłyby słuchane w kontekście „współczesnego Stamitza” wcześniejszych dzieł (prawdopodobnie dodekafonicznych), przypadkowej muzyki elektronicznej, twórczości Pierra Bouleza i Eltona Johna oraz widma zagłady nuklearnej.

Argument 4.5. (5) Jeden z pasaży Koncertu na orkiestrę (1943) Bartoka jest satyra na Siódma symfonię Szostakowicza z 1941 roku, której pompatyczność najprawdopodobniej nie przypadła Bartokowi do gustu. Temat przewodni tej symfonii jest cytowany i muzycznie komentowany w sposób zaprzeczalny. Gdyby jednak Bartok przygotował tę sama partyturę w 1939 roku, to jego kompozycja nie parodiowałaby Szostakowicza, ani nie byłaby wynikiem działań Szostakowicza w 1943 roku.

Oraz w drugim tekście ${ }^{22}$, w odpowiedzi na zarzut Kivy'ego:

Argument 4.6. Reductio ad absurdum stanowiska Kivy'ego można sformułować na przykładzie słusznie sławnego (choć z wątpliwych powodów) Bolera Ravela. Utwór ten, składający się z dziewięciu powtórzeń tej samej melodii i anty-tematu, które zmieniaja się jedynie poprzez instrumentarium, nie miałby żadnego sensu, gdyby został skomponowany na dwa fortepiany, które przecież byłyby w stanie wykonać wszystkie potrzebne dźwięki.

Mój argument i zarazem najważniejsza teza tego tekstu jest taka, że przykłady A.4.1.-A.4.6. są o tyle nieprzekonujące, że zdają się osadzać tożsamość dzieł w cechach, które są niewewnętrzne - w cechach relacyjnych. Levinson przemyca przytoczone analogie dzięki temu, że manipuluje cechami tych obiektów, w których tożsamość wątpi. Mówi, że Sonata opus 2 (1852) Brahmsa ma lisz-

22 Tamże, s. 247. 
towskie wpływy, jednak dzieło o takiej samej strukturze dźwiękowej, ale napisane przez Beethovena, tych wpływów by nie przejawiało. A zatem - chce konkludować Levinson - jeśli dzieła muzyczne rzeczywiście mają te cechy, które postrzegamy, że maja podczas uważnego słuchania, to osoba kompozytora i muzyczno-historyczne tło mają wpływ na tożsamość dzieła.

Podobne usterki odnajduję $\mathrm{w}$ argumentach A.2.4. (za esencjalizmem środków wykonania z przykładu funkcji instrumentarium na cechy sonaty Hammerklavier), A.2.5. (za esencjalizmem środków wykonania z przykładu pozornej rozmowy dwu skrzypiec w koncercie d-moll na dwoje skrzypiec Bacha) oraz A.4.6.: pierwszy cierpi na taką samą słabość, jak przykłady powyżej, tj. argumentując, że stanowi wyzwanie dla pianina, Levinson próbuje konkludować, że napisany na jakikolwiek inny instrument nie byłby tak wyzywający. Odnajduję w tym - ponownie - nieuprawniona próbę umocowania tożsamości dzieła w cechach relacyjnych.

Co więcej, drugi argument, próbujący ustanowić instrumentarium jako konieczną cechę dzieła na przykładzie koncertu Bacha, cierpi nie tylko na wymieniona już usterkę, ale również nie jest zupełnie pewne, czy udowadnia to, co chce udowodnić. Wydaje mi się zupełnie do zaakceptowania twierdzenie, że wspomniana dyskursywna, dialogowa natura utworu zależy nie od użycia dwu par skrzypiec, ale od użycia dwu instrumentów w ogóle. Jeśli się zgodzić z tym, że podobne wrażenie metaforycznej rozmowy dwu instrumentów mogłoby zostać uzyskane za pomoca skrzypiec i fortepianu, gdzie drugi powtarzałby (choć w innej barwie) temat przewodni wprowadzany przez te pierwsze, to okazuje się, że argument ten wcale nie ustanawia konieczności instrumentarium, a tylko konieczność liczebności instrumentarium. To znaczy, że wcale nie udowadnia, że utwór ten z konieczności został napisany na dwie pary skrzypiec, a udowadnia tylko, że został z konieczności napisany na przynajmniej dwa instrumenty.

Taki sam wniosek wystarcza do konkluzji (trzeciego) argumentu A.4.6. z Bolera Ravela. To prawda, że utwór ten straciłby 
swój sens i niepowtarzalny charakter kolejnych części, gdyby został wykonany na dwóch fortepianach. Nie wynika z tego jednak, że wybrane przez Ravela instrumentarium jest konieczne. Wynika jedynie, że konieczne jest instrumentarium składające się z przynajmniej dziewięciu instrumentów o wystarczająco odróżnialnej barwie dźwięku.

Łatwo sprowadzić wszystkie przykłady A.4.1.-A.4.6. Levinsona do niechcianych konsekwencji w sposób bliźniaczo podobny do powyższej linii argumentacji. Zatrzymajmy się przy Sonacie opus 2 Brahmsa i zastanówmy się, co by się stało, zgodnie z teorią Levinsona, gdyby Liszt nie skomponował swoich dzieł. Wynika z tego, że dzieło skomponowane przez Brahmsa po Liszcie i to samo - mogłoby się wydawać - dzieło Brahmsa skomponowane w dokładnie takich samych warunkach za wyjątkiem wpływów Liszta byłoby innym dziełem. Zgubne jednak i wysoce nieprawdopodobne wydaje się osadzanie tożsamości jakiegoś obiektu w okolicznościach dla niego zewnętrznych. Wydaje mi się to tak nieintuicyjne jak twierdzenie, że coś tak centralnie i głęboko zakorzenione, jak tożsamość jakiegoś obiektu, zależy od relacji, w jakich stoją do niego obiekty zewnętrzne. Czy zachodzi faktyczna zmiana w świecie, gdy jakiś obiekt staje się moim ulubionym? W tym obiekcie z pewnością nie. Mówienie, o nim, że jest „moim ulubionym” to tylko mówienie, że stoi do mnie w pewnej relacji, ale nic wewnątrz niego się nie zmienia. Nie zachodzi żadna faktyczna zmiana w moim ulubionym koncercie, gdy przestaje być moim ulubionym, gdy odkryję koncert jeszcze bardziej poruszający. Kontekst intensjonalny nie może mieć wpływu na tożsamość obiektu.

Pomimo ogromnej intuicyjności abstrakcyjnej koncepcji Levinsona i obietnicy zachowania pożądanej komponowalności dzieł muzycznych, napotykamy trudności podajace spójność i siłę jego koncepcji w wątpliwość. Wobec powyższych obiekcji za konieczną uważam próbę przeformułowania teorii Levinsona w sposób, który zminimalizuje funkcję kontekstualizmu muzyczno-historycznego, odnajdując obronę przed sytuacja, gdy dwoje kompozytorów używa w swoich kompozycjach tej samej struktury dźwięków, i tym samym osłabi esencjalizm dzieł. 


\section{Podsumowanie}

Jeśli moja przedstawiona powyżej linia argumentacji jest prawidłowa, to udowadniam w niej trzy tezy.

(1) Zgodnie z teorią Levinsona dzieła muzyczne posiadają niektóre ze swoich własności z konieczności. Ustanawiam tym samym esencjalizm odnośnie do dzieł muzycznych.

(2) Zgodnie $z$ argumentem Forbesa dzieła muzyczne posiadaja nie tylko niektóre ze swoich własności w sposób konieczny, ale niektóre z ich cech koniecznych są również cechami unikalnymi. Ustanawiam tym samym istnienie indywidualnych esencji dzieł muzycznych.

(3) Przeciwko teorii Levinsona wykazuję, że jego teza kontekstualizmu muzyczno-historycznego opiera tożsamość dzieł muzycznych na cechach relacyjnych, co uważam za nieuzasadnione. Ustanawiam tym samym, że choć esencjalizm odnośnie do dzieł muzycznych jest prawdziwy, to nie wszystkie własności dzieł muzycznych sa ich cechami koniecznymi. Ustanawiam tym samym umiarkowany esencjalizm dzieł muzycznych.

\section{Summary}

\section{Jerrold Levinson's Ontology of Musical Works and the Question of the Individual Essence of the Musical Work}

In this paper, I set to analyze the kind of metaphysical essentialism that follows from Jerrold Levinson's ontology of musical works. This paper is structured into three sections. In the first, I reconstruct those parts of Levinson's ontology of musical works that entail essentialism. In the second section, I reconstruct Mackie's (2009) and Forbes' (1985) arguments for the indispensability of the individual essences of particular objects and show that they apply equally well to musical works. In the third, final section, I combine the conclusions of the two previous ones to prove that Levinson's ontology of musical works is compatible with Mackie and Forbes' postulate for the individal essences. I show, however, that even though Levinson correctly ascribes essential properties to musical works, his choice about which of those properties count as essential leads to counterintuitive consequences. I end this paper with a new argument showing that musical works do have essential properties but that they are different from those postulated by Levinson. 
Keywords: philosophy of music, ontology of musical works, metaphysical essentialism, individual essence, modal properties

\section{Bibliografia}

Carrier D., Art without Its Artists, „British Journal of Aesthetics” 1982, nr 22, s. 233 .

Forbes G., The Metaphysics of Modality, Oxford 1985.

Levinson J., Music, Art, and Metaphysics: Essays in Philosophical Aesthetics, Ithaca 1990.

Levinson J., What a Musical Work Is, „Journal of Philosophy” t. 77, nr 1, s. 5-28.

Stevenson C. L., On „What is a Poem?”, „Philosophical Review” 1957, t. 66, nr 3, s. 329-362.

Mackie P., How Things Might Have Been, Oxford 2009.

Margolis J., The Language of Art \& Art Criticism, Wayne 1965.

Plantinga A., The Nature of Necessity, Clarendon 1974, rozdz. 5, sek. 2.

Wollheim R., Art and its Objects, Cambridge 1968. 